\title{
Increased levels of IgG antibodies against peptides of the prostate stem cell antigen in the plasma of pancreatic cancer patients
}

\author{
MASAHIRO TANAKA ${ }^{1,2}$, NOBUKAZU KOMATSU ${ }^{1}$, NAOYOSHI TERAKAWA $^{3}$, \\ YASUAKI YANAGIMOTO ${ }^{3}$, MASAO OKA $^{4}$, TETSURO SASADA ${ }^{5}$, TAKASHI MINE ${ }^{1}$, \\ SHOJIRO GOUHARA ${ }^{1,2}$, SHIGEKI SHICHIJO ${ }^{1,6}$, SEIYA OKUDA ${ }^{2}$ and KYOGO ITOH ${ }^{1,6}$
}

\author{
Departments of ${ }^{1}$ Immunology and ${ }^{2}$ Internal Medicine, Kurume University School of Medicine, Asahi-machi 67, Kurume \\ 830-0011; ${ }^{3}$ Department of Surgery, Kansai Medical School, 10-15 Fumizono-cho, Moriguchi, Osaka 570-8506; \\ ${ }^{4}$ Department of Surgery, Yamaguchi University School of Medicine, Minami-ogushi 1-1-1, Ube 755-8505; \\ ${ }^{5}$ Division of Surgery, Kitano Hospital, Ohgi-machi 2-4-20, Osaka 530-0025; ${ }^{6}$ Center of the 21 st Century \\ COE Program for Medical Science, Kurume University, Kurume, Fukuoka 830-0011, Japan
}

Received January 6, 2007; Accepted February 20, 2007

\begin{abstract}
One of the longstanding challenges in the treatment of pancreatic cancer, the fifth most common cancer worldwide, is to establish a simple and reliable diagnostic marker for the disease. This study examined whether or not the plasma levels of $\mathrm{IgG}$ antibodies (IgGs) reactive to peptides derived from the prostate stem cell antigen (PSCA), which is highly expressed in pancreatic cancer cells, were elevated in patients with pancreatic cancer. Fifty-seven kinds of peptides encoded by PSCA were tested for their reactivity to plasma IgGs of pancreatic cancer patients. The results showed that the levels of IgGs specific to each of the 10 different peptides in the plasma of pancreatic cancer patients were significantly higher than those of non-cancer subjects. Eighty percent of subjects with and $18 \%$ of subjects without pancreatic cancer were diagnosed as having pancreatic cancer, respectively, when those cases showing significantly elevated levels of IgGs against at least one of the three peptides of PSCA at positions 2-11, 85-95, and 109-118 were judged as positive for pancreatic cancer. These results indicate that the measurement of IgGs reactive to these PSCA-derived peptides can provide novel information on the host-tumor interaction in pancreatic cancer, and could potentially be used as a new diagnostic tool to screen for pancreatic cancer.
\end{abstract}

\section{Introduction}

The development of new diagnostic tools has contributed to a remarkable improvement in the prognosis of many cancers,

Correspondence to: Dr Shigeki Shichijo, Department of Immunology, Kurume University School of Medicine, 67 Asahi-machi, Kurume, Fukuoka 830-0011, Japan

E-mail: shichijo@med.kurume-u.ac.jp

Key words: pancreatic cancer, prostate stem cell antigen, antibody, diagnosis, peptide but few improvements have been achieved for the diagnosis of pancreatic cancer. Measurements of the serum levels of the carcinoembryonic antigen (CEA) (1), the sialylated Lewis blood group antigen CA19-9 (2), Du-PAN-2 $(3,4)$, the SPan-1 antigen (5), or Mesothelin $(6,7)$ are not sufficient as reliable diagnostic markers for pancreatic cancer (8). The failure to find an adequate marker could be in part due to our insufficient understanding of the host-tumor interaction in pancreatic cancer. Certain studies have reported several new tumor antigens that are highly expressed in pancreatic cancer cells. One of them is the prostate stem cell antigen (PSCA). PSCA is a glycosylphosphatidyl-inositol-linked cell surface antigen that is expressed in normal prostate cells, and is up-regulated in pancreatic cancer $(9,10)$. In addition, we have reported a dozen pancreatic cancer-associated antigens that were recognized by the cellular immune system as a complex formed of a peptide and the major histocompatibility antigen complex (MHC) class I antigen (11). We have also reported that significant levels of IgGs specific to certain cancerassociated antigens were detectable in the plasma of pancreatic cancer patients prior to the vaccination (12-14). In the present study, therefore, we examined whether or not the plasma levels of $\mathrm{IgG}$ antibodies reactive to PSCA-derived peptides were elevated in pancreatic cancer patients, and found that IgGs reactive to 10 of the 57 kinds of PSCAderived peptides tested were elevated in these patients.

\section{Materials and methods}

Samples. The Institutional Ethics Committees of Kurume University School of Medicine, Yamaguchi University School of Medicine, and Kansai Medical School approved this study protocol. After written informed consent was obtained, the plasma samples were collected. Plasma samples were collected from 40 patients with stage 3 or 4 pancreatic cancer, and 60 non-cancer subjects (16 patients with urolithiasis, 16 with IgA nephropathy, and 28 healthy donors). Plasma samples from patients with colon cancer $(n=16)$, gastric cancer $(n=16)$, and prostate cancer $(n=40)$ were also provided for the study. 
Table I. Peptides encoded by PSCA used in this study.

\begin{tabular}{ll}
\hline Peptide & \multicolumn{1}{c}{ Sequence } \\
\hline & PSCA: HLA-A2 and -A24 \\
\cline { 2 - 2 } PSCA 5-13 & LLALLMAGL \\
PSCA 7-15 & ALLMAGLAL \\
PSCA 43-51 & QLGEQCWTA \\
PSCA 109-117 & LLPALGLPAL \\
PSCA 76-84 & DYYVGKKNI \\
PSCA 4-12 & VLLALLMAG \\
PSCA 106-114 & ILALLPALG \\
PSCA 21-29 & LLCYSCKAQV \\
PSCA 70-79 & QVDDSQDYYV \\
PSCA 108-117 & ALLPALGLPA \\
PSCA 27-36 & KAQVSNEDCL \\
& \\
PSCA 74-82 & PSCA: HLA-A3 \\
\cline { 2 - 2 } PSCA 3-11 & SQDYYY \\
PSCA 105-113 & AVLLALLMA \\
PSCA 108-116 & AILALLPAL \\
PSCA 46-54 & ALLPALGLL \\
PSCA 44-52 & EQCWTARIR \\
PSCA 73-81 & LGEQCWTAR \\
PSCA 82-91 & DSQDYYVGK \\
PSCA 43-52 & KNITCCDTDL \\
PSCA 55-64 & QLGEQCWTAR \\
PSCA 52-61 & AVGLLTVISK \\
PSCA 42-51 & RIRAVGLLTV \\
PSCA 73-82 & TQLGEQCWTA \\
PSCA 76-85 & GTALLCYSCK \\
& DSQDYYVGKK \\
PSCA & DYYVGKKNIT
\end{tabular}

PSCA: Overlap peptides

\begin{tabular}{|c|c|}
\hline PSCA 1-10 & MKAVLLALLN \\
\hline PSCA 5-14 & LLALLMAGLO \\
\hline PSCA $10-19$ & MAGLALQPGT \\
\hline PSCA 11-20 & AGLALQPGTA \\
\hline PSCA 16-25 & QPGTALLCYS \\
\hline PSCA 21-30 & LLCYSCKAQV \\
\hline PSCA 26-35 & CKAQVSNEDC \\
\hline PSCA $31-40$ & SNEDCLQVEN \\
\hline PSCA 36-45 & LQVENCTQLG \\
\hline PSCA 41-50 & CTQLGEQCWT \\
\hline PSCA 46-55 & EQCWTARIRA \\
\hline PSCA 51-60 & ARIRAVGLLT \\
\hline PSCA 56-65 & VGLLTVISKG \\
\hline PSCA $61-70$ & VISKGCSLNC \\
\hline PSCA 66-75 & CSLNCVDDSQ \\
\hline PSCA 71-80 & VDDSQDYYVG \\
\hline PSCA $81-90$ & KKNITCCDTD \\
\hline PSCA 86-95 & CCDTDLCNAS \\
\hline PSCA 91-100 & LCNASGAHAL \\
\hline PSCA 96-105 & GAHALQPAAA \\
\hline PSCA 101-110 & QPAAAILALL \\
\hline PSCA 106-115 & ILALLPALGL \\
\hline PSCA $111-120$ & PALGLLLWGP \\
\hline PSCA 116-123 & LLWGPGQL \\
\hline
\end{tabular}

Table I. Continued.

\begin{tabular}{lc}
\hline Peptide & \multicolumn{1}{c}{ Sequence } \\
\hline & PSCA: Overlap peptides \\
\cline { 2 - 2 } PSCA 2-11 & KAVLLALLMA \\
PSCA 3-12 & AVLLALLMAG \\
PSCA 4-13 & VLLALLMAGL \\
PSCA 6-15 & LALLMAGLAL \\
PSCA 7-16 & ALLMAGLALQ \\
PSCA 8-17 & LLMAGLALQP \\
PSCA 9-18 & LMAGLALQPG \\
\hline
\end{tabular}

PSCA, prostate stem cell antigen. The numbers following PSCA represent the numeric order of the amino acids of the PSCA molecules.

Peptides. The list of PSCA-derived peptides used in this study is given in Table I. i) We prepared 26 kinds of peptides with HLA-A2, -A3 or -A24 binding motifs based on our previous observation that IgG antibodies specific to peptides with HLA-A2, -A3 or -A24 binding motifs were frequently found in the plasma of cancer patients, including patients with pancreatic cancer (12-16). ii) We prepared 24 kinds of decapeptides covering the entire sequence of PSCA. Preliminary experiments indicated that the peptides containing the $\mathrm{N}$ terminus portions of PSCA were reactive to the patients' plasma (data not shown). iii) We additionally prepared 7 kinds of peptides covering positions 1 to 20 of the $\mathrm{N}$-terminal sequence. These peptides were purchased from BioSynthesis, Inc. (Lewisville, TX, USA). Each peptide was dissolved in dimethyl sulfoxide (DMSO), stored at $-80^{\circ} \mathrm{C}$, and diluted with saline just before use.

Preparation of xMAP beads. The XMAP carboxylate beads and Luminex ${ }^{\circledR}$ system platform were obtained from Luminex Corporation (Austin, TX, USA). The 96-well filter plates (MABVN12) and vacuum manifold apparatus (MAVM 09601) were from Millipore Corporation (Bedford, MA, USA). Biotinylated goat anti-human IgG (gamma chainspecific) (BA 3080) was purchased from Vector Laboratories Inc. (Burlingame, CA, USA). Streptavidin-PE (S-866) was purchased from Molecular Probes (Eugene, OR, USA). 1Ethyl-3-[3-dimethylaminopropyl]carbodiimide hydrochloride (EDC, 22980) was obtained from Pierce (Rockford, IL, USA). The peptides were coupled with the XMAP beads according to the modified manufacturer's instructions as reported previously (13). In brief, $100 \mu 1$ of the XMAP beads were washed with $0.1 \mathrm{M}$ MES buffer, $\mathrm{pH} 7.0$, followed by mixing with $100 \mu 1$ peptide $(1 \mathrm{mg} / \mathrm{ml}$ in $0.1 \mathrm{M}$ MES buffer, pH 7.0). The peptide-loaded beads were then incubated with EDC $(1 \mathrm{mg} / \mathrm{ml})$ at room temperature for $30 \mathrm{~min}$ in darkness, then incubated twice more under the same conditions, and the beads were washed with $0.05 \%$ Tween-20 PBS (PBST). Finally, the beads were treated with 2-aminoethanol for $15 \mathrm{~min}$ at room temperature in darkness, then washed twice and resuspended with $1 \mathrm{ml} 0.05 \% \mathrm{NaN}_{3}$ in Block Ace.

Anti-peptide antibody measurement by flow cytometry assay. Peptide-specific IgG levels in the plasma were measured by 

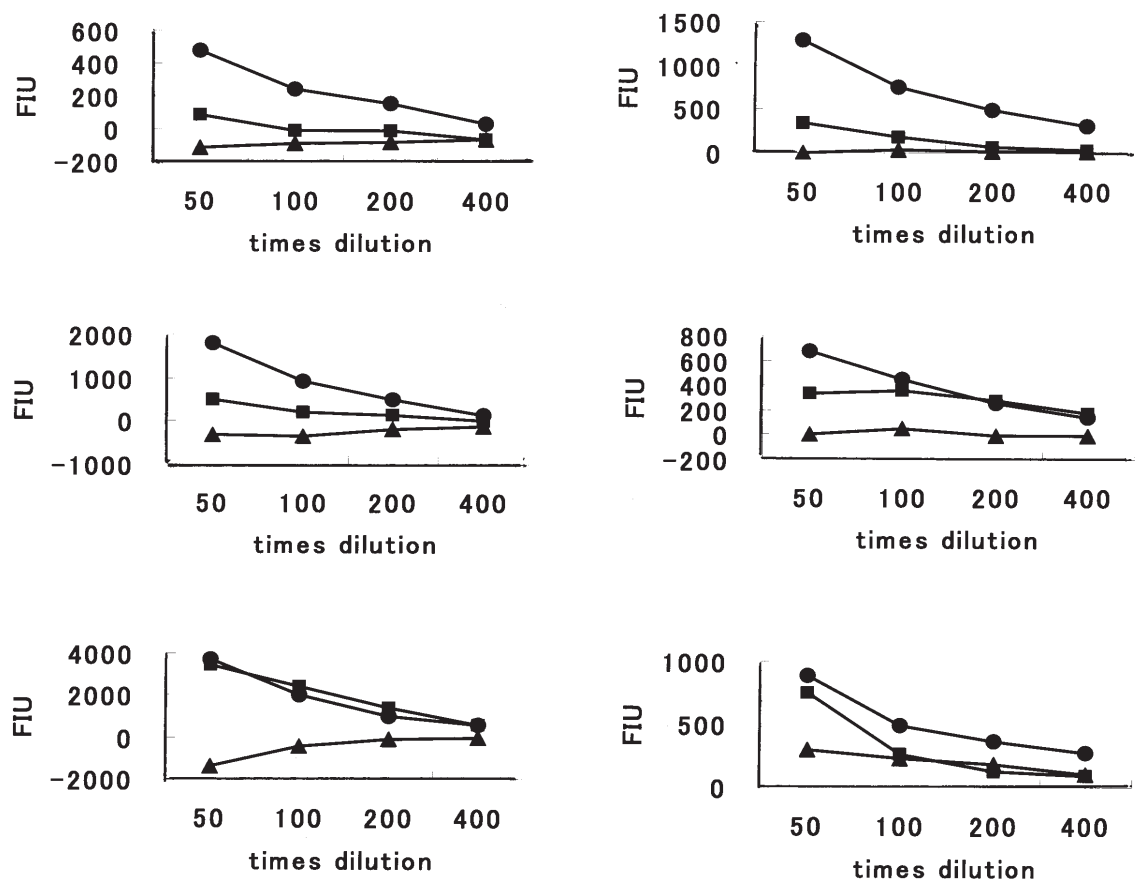

:PSCA2-11, 口:PSCA86-95, А:PSCA109-117

Figure 1. Dose-dependency of IgG antibodies (IgGs) reactive to prostate stem cell antigen (PSCA) peptides. The antibody levels in the plasma collected from 6 different pancreatic cancer patients were measured by means of a multiplex beads suspension array using the Luminex ${ }^{\circledR}$ system described in 'Materials and methods'. Values represent the fluorescence intensity units of the antigen-specific Igs.

flow cytometry assay using the Luminex ${ }^{\circledR}$ system as reported previously (13). In brief, the plasma was incubated with $170 \mu 1$ of the peptide-coded beads for $2 \mathrm{~h}$ at room temperature in a 96-well filter plate on a plate shaker. After incubation, the plate was washed using a vacuum manifold apparatus and incubated with $100 \mu \mathrm{l}$ biotinylated goat anti-human IgG (gamma chain-specific) for $1 \mathrm{~h}$ at room temperature on a plate shaker. The plate was then washed, $100 \mu 1$ streptavidin-PE were added to the wells, and the plate was incubated for $40 \mathrm{~min}$ at room temperature on a plate shaker. The bound beads were washed three times followed by the addition of $100 \mu 1$ PBST into each well, and the plate was then placed for 3 min on a plate shaker.

Adsorption test of antibodies against peptides. For the preparation of the peptide immobilized ELISA plate for the antibody absorption test, the peptides were diluted in $0.1 \mathrm{M}$ carbonate buffer containing a chemical cross-linker, disuccinimidyl suberate (Pierce), as reported previously (13). ELISA plates were coated overnight at $4^{\circ} \mathrm{C}$ with the target peptides $(20 \mu \mathrm{g} /$ well). The wells were rinsed three times with $0.05 \%$ PBST. The plates were blocked overnight at $4^{\circ} \mathrm{C}$ with Block Ace. To test the specificity of the anti-peptide IgG, $100 \mu \mathrm{l} /$ well of plasma samples (1:1000 dilution with $0.05 \%$ PBST) were absorbed with the immobilized peptide $(20 \mu \mathrm{g} / \mathrm{well})$ in wells kept for $2 \mathrm{~h}$ at room temperature. The absorption was repeated three times, and then the level of the peptide-specific $\operatorname{IgG}$ in the resultant supernatant was measured.

Statistics. The statistical significance of the data was determined using the two-tailed Student's t-test. A P-value of $<0.05$ was considered statistically significant.

\section{Results}

Antibodies against PSCA peptides. First, we used a serial dilution of the samples to determine whether or not the levels of $\mathrm{IgGs}$ reactive to the PSCA peptides in the plasma of pancreatic cancer patients were dose-dependent. The level of the antibody was given in fluorescent intensity units (FIU). The results showed that the levels of antibodies to the PSCAderived peptides at positions 2-11 (PSCA 2-11) and 86-95 (PSCA 86-95) in pancreatic cancer patients were gradually decreasing according to the serial dilution of the samples; representative cases are shown in Fig. 1. Although the level was relatively low, the antibody titers in non-cancer subjects also decreased in a dilution-dependent manner (data not shown). Based on these results, 100-fold dilutions of the samples were used for the assays in the following experiments.

Next, we investigated the levels of anti-peptide antibodies in the plasma of pancreatic cancer patients $[n=40,(31$ males and 9 females; mean age, 65 years)] and those of the agematched healthy donors [ $\mathrm{n}=29$, (16 males and 13 females; mean age, 64 years)]. The results showed that the levels of IgGs against 15 of the 57 peptides tested were significantly $(\mathrm{P}<0.05$ by a two-tailed Student's t-test) higher in the pancreatic patients than in the non-cancer subjects (Table II).

We then provided the plasma from the different types of cancer, and investigated the levels of anti-peptide antibodies reactive to these 15 peptides in patients with pancreatic $(n=40)$, prostate $(n=38)$, colon $(n=20)$, and gastric cancer $(n=20)$. Plasma samples from subjects without cancer $[n=60$, (16 patients with urolithiasis, 16 with $\operatorname{IgA}$ nephropathy, and 28 healthy donors)] were used as the control. The levels of antibodies reactive to each of the 10 of the 15 peptides shown 
Table II. Antibodies against PSCA-encoded peptides in pancreatic cancer patients and the age-mached non-cancerous controls.

\begin{tabular}{lrrrrrr}
\hline & \multicolumn{2}{c}{$\begin{array}{c}\text { Pancreatic cancer } \\
\text { patients }\end{array}$} & & \multicolumn{2}{c}{$\begin{array}{c}\text { Non-cancerous } \\
\text { control }\end{array}$} \\
\cline { 2 - 3 } Peptides & Mean & SD & & Mean & SD & P \\
\hline PSCA 2-11 & 1516 & 964.5 & & 813 & 438.5 & 0.0001 \\
PSCA 3-11 & 412 & 220.8 & & 160 & 139.4 & 0.0000 \\
PSCA 3-12 & 424 & 239.5 & & 192 & 146.1 & 0.0000 \\
PSCA 8-17 & 504 & 367.2 & & 226 & 144.4 & 0.0001 \\
PSCA 18-27 & 402 & 362.7 & & 223 & 192.9 & 0.0105 \\
PSCA 27-36 & 428 & 518.3 & & 215 & 251.5 & 0.0281 \\
PSCA 43-51 & 533 & 796.2 & & 240 & 349.0 & 0.0435 \\
PSCA 44-52 & 999 & 1672.3 & & 404 & 520.1 & 0.0398 \\
PSCA 51-60 & 536 & 562.5 & & 277 & 291.9 & 0.0155 \\
PSCA 55-64 & 565 & 577.7 & & 279 & 282.0 & 0.0086 \\
PSCA 56-65 & 589 & 677.1 & & 312 & 337.9 & 0.0297 \\
PSCA 86-95 & 4323 & 3481.1 & & 2115 & 2349.9 & 0.0025 \\
PSCA 105-113 & 262 & 283.7 & & 147 & 187.8 & 0.0472 \\
PSCA 108-117 & 415 & 485.1 & & 225 & 273.9 & 0.0431 \\
PSCA 109-117 & 175 & 457.8 & & 45 & 458.0 & 0.0417 \\
\hline
\end{tabular}

PSCA, prostate stem cell antigen; SD, standard deviation. The IgG levels of antibodies against each of the peptides were significantly higher in the plasma of pancreatic cancer patients $(n=40)$ than in those of the age-matched controls, including the healthy donors $(n=29)$.

in Table II were significantly higher in the pancreatic than in the non-cancer subjects (Table III). Furthermore, the levels of antibodies to each of the 8,4 , or 2 of these 10 peptides in the plasma of colon, gastric, or prostate cancer patients were significantly higher than those of non-cancer subjects, respectively. In addition, the antibody levels to PSCA 86-95 in pancreatic or colon cancer patients were also significantly higher than those of prostate cancer patients, which in turn were higher than those of non-cancer subjects.

Lack of correlation between the level of CA19-9 and antibody levels against 10 peptides. The correlation between the level of CA19-9, one of the standard biomarkers for the diagnosis of pancreatic cancer, and the levels of antibodies against each of the 10 peptides shown in Table III was investigated in 20 pancreatic cancer patients whose CA19-9 values were available for the study. However, the serum levels of CA19-9 did not correlate with the levels of antibodies reactive to any of the 10 peptides in the plasma of these 20 pancreatic cancer patients (data not shown).

Cumulative analysis with antibodies against 3 different peptides. From a diagnostic point of view, the cut-off level of antibodies was set as the mean plus standard deviation (SD) of the non-cancer subjects, and if an antibody level was higher than the cut-off level, the patients were judged as being positive for pancreatic cancer. Under these conditions, the positive cases were $22,4,4,9,8,7,8,21,11$, and 12 out of 40 pancreatic cancer patients when the antibody levels against PSCA 2-11, 3-11, 3-12, 18-27, 27-37, 44-52, 51-60, 86-95, 108-117, and 109-118 were used as biomarkers. On the contrary, the false-positive cases were $6,3,3,4,4,4,6,4$, and 3 out of 60 non-cancer subjects. We then conducted a cumulative analysis to determine the marker with the highest diagnostic value for pancreatic cancer. The results showed that $80 \%$ of subjects with and $18 \%$ of subjects without pancreatic cancer were diagnosed as having pancreatic cancer, respectively, when those cases showing significantly elevated levels of IgGs against at least one of the three peptides of PSCA at positions 2-11, 85-95, and 109-118 were judged as positive for pancreatic cancer. Under the same conditions, $80 \%$ of the colon cancer patients, $90 \%$ of gastric cancer, and $45 \%$ of the prostate cancer patients were diagnosed as having colon, gastric, and prostate cancer, respectively (Table IV).

Table III. Antibodies against PSCA-encoded peptide fragments in cancer and non-cancer subjects.

\begin{tabular}{|c|c|c|c|c|c|c|c|c|c|c|c|c|c|c|c|c|}
\hline \multirow[b]{2}{*}{ Peptides } & \multicolumn{4}{|c|}{ Pancreas } & \multicolumn{3}{|c|}{ Colon } & \multicolumn{4}{|c|}{ Gastric } & \multicolumn{3}{|c|}{ Prostate } & \multicolumn{2}{|c|}{ Non-cancer } \\
\hline & Mean & SD & vs NC & vs Prost & Mean & SD & vs NC & Mean & SD & vs NC & vs Prost & Mean & SD & vs NC & Mean & SD \\
\hline PSCA 2-11 & 1516 & 964.5 & 0.0000 & & 1515 & 778.0 & 0.0000 & 1786 & 659.2 & 0.0000 & 0.0182 & 1190 & 1238.8 & 0.0056 & 565 & 712.4 \\
\hline PSCA 3-11 & 412 & 220.8 & 0.0166 & & 463 & 294.2 & 0.0142 & 438 & 225.8 & 0.0143 & & 845 & 2756.8 & & 220 & 542.5 \\
\hline PSCA 3-12 & 424 & 239.5 & 0.0130 & & 474 & 380.9 & 0.0312 & 460 & 268.5 & 0.0131 & & 676 & 2048.4 & & 237 & 488.1 \\
\hline PSCA 27-36 & 428 & 518.3 & 0.0340 & & 560 & 738.0 & & 289 & 312.7 & & & 783 & 2757.7 & & 210 & 448.6 \\
\hline PSCA 44-52 & 999 & 1672.3 & 0.0354 & & 1545 & 2267.7 & 0.0365 & 509 & 625.4 & & & 1224 & 3419.8 & & 389 & 746.9 \\
\hline PSCA 51-60 & 536 & 562.5 & 0.0064 & & 765 & 926.3 & 0.0219 & 387 & 403.3 & & & 990 & 3180.8 & & 233 & 468.3 \\
\hline PSCA 86-95 & 4323 & 3481.1 & 0.0000 & 0.0014 & 3113 & 1666.5 & 0.0000 & 3841 & 2212.5 & 0.0000 & 0.0081 & 2150 & 2202.7 & 0.0127 & 1075 & 1818.4 \\
\hline PSCA 108-117 & 934 & 1358.6 & 0.0052 & & 1549 & 2206.3 & 0.0190 & 648 & 837.1 & & & 1072 & 3007.4 & & 277 & 485.6 \\
\hline PSCA 109-118 & 124 & 463.6 & 0.0182 & & 376 & 1067.9 & & -80 & 363.3 & & & 247 & 1718.5 & & -130 & 387.7 \\
\hline
\end{tabular}

PSCA, prostate stem cell antigen; SD, standard deviation; Prost, prostate. Antibodies against each of the PSCA-encoded peptide fragments in colon ( $\mathrm{n}=20$ ), gastric ( $\mathrm{n}=20$ ), pancreatic $(n=40)$, and prostate $(n=40)$ cancers, and the same from non-cancer subjects $(n=60)$, including those with urolithiasis ( $n=16)$ and IgA nephropathy ( $n=16)$ and healthy donors $(n=28)$, were tested. 
Table IV. Cumulative analysis of antibodies against different epitopes of PSCA molecules.

\begin{tabular}{|c|c|c|c|c|c|}
\hline \multirow[b]{2}{*}{ Patients } & \multicolumn{5}{|c|}{ 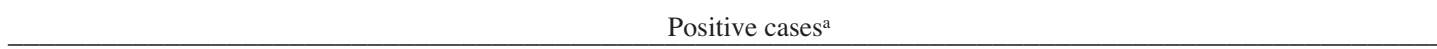 } \\
\hline & $\begin{array}{c}\text { Number of } \\
\text { patients }\end{array}$ & PSCA 2-11 (\%) & PSCA 86-95 (\%) & PSCA $109-118(\%)$ & Positive (\%) \\
\hline Pancreas & $\mathrm{n}=40$ & $22(55)$ & $21(52.5)$ & $12(30)$ & $32(80)^{\mathrm{b}}$ \\
\hline Colon & $\mathrm{n}=20$ & $14(70)$ & $11(55)$ & $5(25)$ & $16(80)$ \\
\hline Gastric & $\mathrm{n}=20$ & $15(75)$ & $14(70)$ & $2(10)$ & $18(90)$ \\
\hline Prostate & $\mathrm{n}=40$ & $14(35)$ & $8(20)$ & $6(15)$ & $19(45)$ \\
\hline Non-cancer & $\mathrm{n}=60$ & $6(10)$ & $6(10)$ & $3(11.1)$ & $11(18.3)^{\mathrm{b}}$ \\
\hline
\end{tabular}

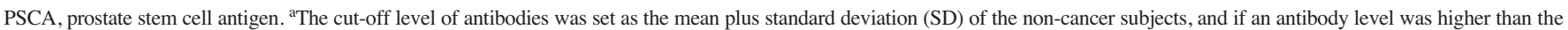
cut-off level, the patients were judged as being positive for pancreatic cancer. ${ }^{b}$ Eighty percent of subjects with and $18 \%$ of subjects without pancreatic cancer were diagnosed as having pancreatic cancer, respectively, when those cases showing significantly elevated levels of IgGs against at least one of the three peptides of PSCA at positions 2-11, 85-95, and 109-118 were judged as positive for pancreatic cancer.

Specificity of anti-peptide activities. The specificity of antipeptide activities was investigated by absorption tests. Plasma samples from pancreatic patients were incubated with each of the 3 peptides shown in Table IV. The reactivity was largely reduced by absorption with the corresponding peptide, but not with the irrelevant peptides tested in the case of PSCA 2-11 and 86-95 (data not shown). In the cases of PSCA 2-11 and 109-118, however, the reactivity was not reduced by absorption with the corresponding peptide nor with the irrelevant peptides tested.

\section{Discussion}

We reported in this study that the levels of IgGs to 10 of the 57 peptides of PSCA were elevated in the plasma of patients with relatively advanced stages of pancreatic cancer (stage 3 or 4) relative to the levels in the non-cancerous controls. The higher levels of antibodies could be explained partly by the higher expression of PSCA in pancreatic cancer cells $(9,10)$, although the tumor samples were not available to measure the expression levels of PSCA. Namely, the higher levels of PSCA expression in pancreatic cancer cells could induce a much stronger immune response to PSCA, resulting in higher levels of production of IgGs reactive to PSCA-derived peptides as compared to the regular levels of immune responses to these peptides in non-cancer subjects. Among these 10 peptides, 4 peptides (PSCA 2-11, 3-11, 3-12, and 8-17) shared the common 4 amino-acid sequence (LLMA), suggesting that this sequence could be one of the dominant epitopes.

The specificity of the anti-PSCA 86-95 activity was confirmed, whereas the broad reactivity of the anti-PSCA 2-11 or 109-118 activity was shown by means of an absorption test. This broad reactivity could be due to the shared B cell epitope between the PSCA 109-118 peptide and unidentified immunodominant epitopes, although the details are unclear at the present time.

One particular study revealed than PSCA-positive circulating tumor cells were found in the blood of patients with gastrointestinal cancers (17), which could be responsible for the higher levels of IgGs reactive to the PSCA-derived peptides in colon and gastric cancer patients. Namely, the plasma of colon and gastric cancer patients showed higher levels of IgGs against 8 and 4 peptides among the 10 peptides to which the plasma of pancreatic cancer patients also showed the higher levels as compared to those of the non-cancer subjects. In contrast, IgGs to only 2 of these 10 peptides were found to be elevated in prostate cancer patients, regardless of the fact that PSCA was expressed in the normal prostate with a much higher expression in prostate cancer cells (18). This discrepancy needs to be confirmed by a study of larger scale.

The measurement of the serum levels of the carcinoembryonic antigen (CEA) (1), the sialylated Lewis blood group antigen CA19-9 (2), Du-PAN-2 $(3,4)$, and the SPan-1 antigen (5), or Mesothelin $(6,7)$ are not sufficient as reliable diagnostic markers for pancreatic cancer when used individually (8). However, their combined use significantly increases the rate of diagnosis for pancreatic cancer $(8,19)$.

In this study, we found no correlation between the levels of CA19-9 and those of anti-PSCA-derived peptides. Therefore, the combined measurement of CA19-9 and antibody levels to the PSCA peptides shown in this study could increase the diagnostic rate for pancreatic cancer. This issue, however, needs to be confirmed by a study of larger scale. In addition, the correlation of markers other than CA19-9 and the antibody levels to these 3 PSCA peptides should also be studied.

Our results showed that $80 \%$ of subjects with and $18 \%$ of subjects without pancreatic cancer were diagnosed as having pancreatic cancer, respectively, when those cases showing significantly elevated levels of IgGs against at least one of the three peptides of PSCA at positions 2-11, 85-95, and 109118 were judged as positive for pancreatic cancer. Some of the false-negative cases could have depressed the immune responses to PSCA. Alternatively, the tumor samples of the false-negative cases expressed no or low levels of PSCA, although the tumor samples from the patients were not measured in this study. False-positive cases can show stronger immune responses either to self-antigens in a nonspecific manner or to non-self antigens that share the epitope homology with the three PSCA peptides.

A large scale study is needed to confirm the elevation of IgGs to PSCA-derived peptides in the plasma of pancreatic cancer patients. Furthermore, samples from pancreatic cancer 
patients in earlier stages should also be studied. Regardless of these limitations, the measurement of IgGs reactive to these PSCA-derived peptides could provide novel information on the host-tumor interaction in pancreatic cancer, and could potentially be used as a new diagnostic tool to screen for pancreatic cancer.

\section{Acknowledgements}

This study was supported in part by Grants-in-Aid from the Ministry of Education, Science, Sport, Culture and Technology of Japan (no. 17016074 to K.I.), from the Japan Society for the Promotion of Science (no. 18591532 to S.S.), and from the Research Center of Innovative Cancer Therapy of the 21st Century COE Program for Medical Science (to K.I. and S.S.).

\section{References}

1. Denk H, Tappeiner G, Eckerstorfer R and Holzner JH: Carcinoembryonic antigen (CEA) in gastrointestinal and extragastrointestinal tumors and its relationship to tumor-cell differentiation. Int J Cancer 10: 262-272, 1972.

2. Safi F, Roscher R and Beger HG: The clinical relevance of the tumor marker CA 19-9 in the diagnosing and monitoring of pancreatic carcinoma. Bull Cancer 77: 83-91, 1990.

3. Sawabu N, Toya D, Takemori Y, Hattori N and Fukui M: Measurement of a pancreatic cancer-associated antigen (DUPAN-2) detected by a monoclonal antibody in sera of patients with digestive cancers. Int J Cancer 37: 693-696, 1986.

4. Metzgar RS, Rodriguez N, Finn OJ, Lan MS, Daasch VN, Fernsten PD, Meyers WC, Sindelar WF, Sandler RS and Seigler HF: Detection of a pancreatic cancer-associated antigen (DU-PAN-2 antigen) in serum and ascites of patients with adenocarcinoma. Proc Natl Acad Sci USA 81: 5242-5246, 1984.

5. Kawa S, Tokoo M, Oguchi H, Furuta S, Homma T, Hasegawa Y, Ogata $\mathrm{H}$ and Sakata K: Epitope analysis of SPan-1 and DUPAN-2 using synthesized glycoconjugates sialyllact-Nfucopentaose II and sialyllact-N-tetraose. Pancreas 9: 692-697, 1994.

6. McCarthy DM, Maitra A, Argani P, Rader AE, Faigel DO, Van Heek NT, Hruban RH and Wilentz RE: Novel markers of pancreatic adenocarcinoma in fine-needle aspiration: mesothelin and prostate stem cell antigen labeling increases accuracy in cytologically borderline cases. Appl Immunohistochem Mol Morphol 11:238-243, 2003.

7. Argani P, Iacobuzio-Donahue C, Ryu B, Rosty C, Goggins M, Wilentz RE, Murugesan SR, Leach SD, Jaffee E, Yeo CJ, Cameron JL, Kern SE and Hruban RH: Mesothelin is overexpressed in the vast majority of ductal adenocarcinomas of the pancreas: identification of a new pancreatic cancer marker by serial analysis of gene expression (SAGE). Clin Cancer Res 7: 3862-2868, 2001
8. Lucarotti ME, Habib NA, Kelly SB, Rothnie ND, Nelson O, Lindholm L, Cooper MJ, Wood CB and Williamson RC: Clinical evaluation of combined use of CEA, CA19-9 and CA50 in the serum of patients with pancreatic carcinoma. Eur J Surg Oncol 17: 51-53, 1991

9. Argani P, Rosty C, Reiter RE, Wilentz RE, Murugesan SR, Leach SD, Ryu B, Skinner HG, Goggins M, Jaffee EM and Yeo CJ: Discovery of new markers of cancer through serial analysis of gene expression: prostate stem cell antigen is overexpressed in pancreatic adenocarcinoma. Cancer Res 61: 4320-4324, 2001

10. Reiter RE, Gu Z, Watabe T, Thomas G, Szigeti K, Davis E, Wahl M, Nisitani S, Yamashiro J, Le Beau MM, Loda M and Witte ON: Prostate stem cell antigen: a cell surface marker overexpressed in prostate cancer. Proc Natl Acad Sci USA 95: 1735-1740, 1998.

11. Ito M, Shichijo S, Tsuda N, Ochi M, Harashima N, Saito N and Itoh K: Molecular basis of $\mathrm{T}$ cell-mediated recognition of pancreatic cancer cells. Cancer Res 61: 2038-2046, 2001.

12. Nakatsura T, Senju S, Ito M, Nishimura Y and Itoh K: Cellular and humoral immune responses to a human pancreatic cancer antigen, coactosin-like protein, originally defined by the SEREX method. Eur J Immunol 32: 826-836, 2002.

13. Komatsu N, Shichijo S, Nakagawa M and Itoh K: New multiplexed flow cytometric assay to measure anti-peptide antibody: a novel tool for monitoring immune responses to peptides used for immunization. Scand J Clin Lab Invest 64: 535-545, 2004.

14. Yamamoto K, Mine T, Katagiri K, Suzuki N, Kawaoka T, Ueno T, Matsueda S, Yamada A, Itoh K, Yamana $\mathrm{H}$ and Oka M: Immunological evaluation of personalized peptide vaccination for patients with pancreatic cancer. Oncol Rep 13: 875-883, 2005.

15. Mine T, Sato Y, Noguchi M, Sasatomi T, Gohara R, Tsuda N, Tanaka S, Shomura H, Katagiri K, Rikimaru T, Shichijo S, Kamura T, Hashimoto T, Shirouzu K, Yamada A, Todo S, Itoh K and Yamana $\mathrm{H}$ : Humoral responses to peptides correlate with overall survival in advanced cancer patients vaccinated with peptides based on pre-existing, peptide-specific cellular responses. Clin Cancer Res 10: 929-937, 2004.

16. Matsueda S, Takedatsu H, Yao A, Tanaka M, Noguchi M and Itoh K: Identification of peptide vaccine candidates for prostate cancer patients with HLA-A3 supertype alleles. Clin Cancer Res 11: 6933-6943, 2005.

17. Lukyanchuk VV, Friess H, Kleeff J, Osinsky SP, Ayuni E, Candinas D and Roggo A: Detection of circulating tumor cells by cytokeratin 20 and prostate stem cell antigen RT-PCR in blood of patients with gastrointestinal cancers. Anticancer Res 23: 2711-2716, 2003.

18. Gu Z, Thomas G, Yamashiro J, Shintaku IP, Dorey F, Raitano A, Witte ON, Said JW, Loda M and Reiter RE: Prostate stem cell antigen (PSCA) expression increases with high gleason score, advanced stage and bone metastasis in prostate cancer. Oncogene 19: 1288-1296, 2000.

19. Zhao XY, Yu SY, Da SP, Bai L, Guo XZ, Dai XJ and Wang YM: A clinical evaluation of serological diagnosis for pancreatic cancer. World J Gastroenterol 4: 147-149, 1998. 